\title{
Global Warming Versus Global Cooling and Their Impacts on Plants and Animals
}

\author{
Sanjib Kumar \\ ( Principal, B.S.S. College, Supaul-852 131, Bihar, India
}

\begin{abstract}
At global level the disturbance in climate is continued and as an additional effect of global warming, the surprising truth of global cooling is haunting. Since the last decade there is a decreasing trend in global temperature. The year 2011 was recorded as the coolest year globally since 2000. The winter period is being longer both in intensity and duration. The decline in global temperature is creating abnormal climatic change. The incidence of abnormal heavy snow fall, stormy rains with hails in different parts of the world is depicting an upward trend every year. Recently on 16th February 2011, the north-eastern Koshi region of Bihar was badly affected by the erratic climatic change. Supaul district was the worst affected. At about 6 P.M., a sharp shortlived storm with rains and large-sized stony hails came and heavily damaged the standing crops and other plants. Up to 2 feet thick layer of hails accumulated on the roads, courtyards and pucca buildings. It remained for a long durations in condensed state and created great problems. According to the Govt. report the total crops growing in more than 32707 hectares of land were completely destroyed. About 19804 houses were damaged. The largest damage was recorded in Pipra block where crops in about 6193 hectares of land were fully landed down and about 18000 houses destroyed. The wheat and maize crop fields became totally barren and the entire fields changed into pastures for the animals. The banana, mango and litchi crops were also damaged badly. Several vehicles and thatched, asbestos and khapra buildings were demolished. There is an official record of death of at least one female and several animals due to this abnormal stony hailing. Nests of birds with eggs and premature birds were completely destroyed. Several birds in the field were found dead. Even after hailing the newly grown maize crops also depicted the inability of grain formation. This may be due to faulty seeds sowing or due to an extreme coldness after sowing of the seeds.
\end{abstract}

Keywords: Animals, Buildings, Crops, Damage, Global cooling, Snowfall, Damage

\section{Introduction}

The quantity of green house gases is continuously increasing in the atmosphere due to human activities related to industries, transportation and modernization by which temperature of the earth is increasing gradually. This phenomenon is called global warming. It is estimated that at the end of $21^{\text {st }}$ century the average atmospheric temperature will rise up to $1.4-5.8^{0} \mathrm{C}$ [1]. The increase in global temperature may cause melting of ice caps or glaciers by which the level of sea water can rise up and some coastal areas and low lying islands may be submerged [1]. The melting of solid ice means an invitation to cold. In between a long discussion of global warming a surprising truth of global cooling has come forward. When the temperature increases rapidly then the fast melting of ice takes place. It is a scientific fact that when snow falls and is still in a solid state it does not cause coldness but when it melts it produces an extreme coldness. The situation is advancing now. Global warming will produce warmness which will cause melting of ice and then the situation of global cooling will spread [2].

At global level the disturbance in climate is till continued which is appearing in the form of global cooling as the additional effect of global warming [3]. Since the last decade there is a decreasing trend in average global temperature and the year 2011 was recorded as the coolest year globally since 2000 and year 2012 is expected to be cooler than that of the year 2011 [4]. The decrease in global temperature is causing abnormal climatic changes. The incidence of increasing heavy snow fall, stormy rains, hail storms, longer cold period, abrupt cooling, intense cold, erratic climate etc. is showing upward trend every year in different parts of the world including India. All the events indicate that climatic change is doing something which was never before. Let us memorize some interesting events related to global environmental cooling-

1. In December 2004, lower mountain ranges of H.P. were covered with snow [2].

2. In 2005 random hail storm caused excessive coldness in the city like Mumbai [ 2].

3. In winters of 2008 ice crystals were found in crop field of Pusa Institute [2]

4. In 2009 ice crystals were found on India Gate [ 2].

5. Heavy snow fall in Feb 2010 jammed the traffic in about $920 \mathrm{~km}$ range in Belgium. 
6. In February 2010 about 2 feet thick piling of ice was recorded due to heavy snow fall in the entire east areas of USA including Washington (up to $139 \mathrm{~cm}$ ), Philadelphia, New Year, Baltimore and others.

7. In January 2011, 7000 buffaloes died of cold in Vietnam, bitter cold set records in Korea, 800000 animals lost from cold in Mongolia and snow flattened 100,000 homes in china [5].

8. In February 2011, Moscow had the coldest winter in 100 year, record low temperatures in San Francisco and Philadelphia shattered snowfall recerds [5].

9. In February 2011 stormy rains with heavy stony hails extensively damaged the standing crops and buildings in Supaul District of Bihar [6].

10. On $5^{\text {th }}$ February 2012, heavy snow fall caused cancellation of about 1200 flights in London. Temperature in several areas of Europe cooled down to $-3^{\circ} \mathrm{C}$ [7].

11. On $13^{\text {th }}$ February 2012, Srinagar became completely covered with snow [8].

Thus the changing climate of earth is warning regarding the forthcoming danger. Recently some northeastern districts of Bihar have experienced the ill effects of the erratic behaviour of climatic changes which occurred on February 2011 evening. Supaul District was the worst affected. Heavy stormy rains with large-sized stony hail storm extensively damaged the standing crops, plants, animals and buildings. Hence, it was thought necessary to estimate the damage caused by this hail storm which created a situation of disaster in Supaul district.

\section{Materials And Methods}

Supaul District is a north-eastern district of Bihar in India. It lies adjacent to the international boundary of Nepal. This area is very much sensitive to natural calamities due to its geographical and ecological features. It has been included under the first step of eight selected district for disaster management programme by the State Government. People of this district are affected extensively every year by the floods brought about by the Koshi and Aghwara rivers. Besides this Supaul district is situated in the most earthquake prone zone which further increases its sensitive for natural calamities [9].

An extensive study was made after stormy rains and hail storm in the affected blocks of Supaul District. The survey was undertaken on the next and a few consecutive days that is on $17^{\text {th }}$ February 2011 and thereafter because it was not possible to come out of the house on the day due to heavy hails on the road, raining and extreme cold. Affected areas including roads, building, crop lands, plants etc. were photographed and people were asked for their experiences and damages caused by the hail storm.

\section{Results And Discussion}

Damage of crops in different block of Supaul district due to stormy rains and hails are depicted in Table-1 Altogether 6 block of Supaul district viz. Supaul, Kishanpur, Pipra, Triveniganj, Chhatapur and Marauna were extensively damaged by hail storm. Crops growing in about 32707 hectares of land of these six blocks were totally destroyed [10]. Largest damage was done in Pipra block where crops growing in about 6193 hectares were completely landed down. Important standing crops damaged due to hailstorm were wheat, maize, pulses, oil seeds and others. Wheat crop was largely damaged (26027 hectare land) followed by pulses (2382 hectare), maize (2022 hectare), oilseeds (1459 hecture) and others ( 817 hectare). The hail storm also destroyed the standing crops of banana, litchi and mango. The entire crop land of these blocks changed into the pastures for animals. There is a report of death of one female Sulekha Devi of Amaha Panchayat of Pipra block [11]. Several domestic animals injured and severals birds lost their lives.

The devastating nature of hail storm can be imagined by the fact that about $2.5-3.0 \mathrm{~kg}$ stony hails were found at several places of Pipra. Some people reported up to $10 \mathrm{~kg}$ of hails. Road, courtyards, pucca roofs, crop lands, fields become completely covered with hails. At several places hails freezed to form more than 2 feet thick layer of ice. People faced a lot of troubles. The transportation in this areas was completely blocked for several hours. This abrupt heavy hail storm with rain extecmely cooled down the temperature of the environments and this situation remained for few days. After sun rise people felt more coldness. Met Office and the University of East Anglia Climatic Research Unit also confirms that the rising trend in world temperature has already ended in 1997 and we are even be heading for a mini ice age [12]. According to Easterbrook [13] the global warming (i.e. the warming since1977) is over and the global cooling has began about $2005 t_{-} 3-5$ years. The minute increase of anthropogenic CO2in the atmosphere $(0.008 \%)$ was not the cause of warming - it was acontinuation of natural cycle that occurred over the past 500 years. The Pacific Ocean has an alternate warm temperature mode and a cool temperature modeof every 25 - 30 years known as Pacific Decadal Oscillation (PDO). The PDO cool mode has replaced the warm mode in the Pacific Ocean right on the schedule as predicted by last climate and PDO changes. It virtually assures us of about 30 years of global cooling up to 2030, perhaps much deeper than the global cooling from about $1945-1977$. 
Table - 01: Damage Of Crops In Different Blocks Of Supaul District Due To Stormy Rains And Hails On $16^{\text {th }}$ Feb. 2011

\begin{tabular}{|c|c|c|c|c|c|c|c|}
\hline \multirow[t]{2}{*}{ S.N. } & \multirow{2}{*}{$\begin{array}{lll}\text { NAME } & \text { OF } & \text { THE } \\
\text { BLOCK } & & \\
\end{array}$} & \multicolumn{6}{|c|}{ DAMAGE OF CROPS (IN HECTARE) } \\
\hline & & WHEAT & MAIZE & PULSES & $\begin{array}{l}\text { OIL } \\
\text { SEEDS }\end{array}$ & $\begin{array}{l}\text { OTHR } \\
\text { CROPS }\end{array}$ & TOTAL \\
\hline 1 & SUPAUL & 3448 & 342 & 212 & 248 & 92 & 4442 \\
\hline 2 & KISHANPUR & 5000 & 400 & 530 & 252 & 88 & 6270 \\
\hline 3 & PIPRA & 4922 & 400 & 510 & 269 & 92 & 6193 \\
\hline 4 & TRIVENIGANJ & 3985 & 297 & 392 & 188 & 250 & 5112 \\
\hline 5 & CHHATAPUR & 5840 & 342 & 448 & 397 & 175 & 7202 \\
\hline 6 & MARAUNA & 2832 & 241 & 290 & 105 & 20 & 3488 \\
\hline \multicolumn{2}{|c|}{ TOTAL } & 26027 & 2022 & 2382 & 1459 & 817 & 32707 \\
\hline
\end{tabular}

(Source : DDMA, Supaul, 2011)

TABLE - 02 : DAMAGE OF BUILDINGS IN DIFFERENT BLOCKS OF SUPAUL DISTRICT DUE TO STORMY RAINS AND HAILS ON $16^{\mathrm{TH}}$ FEB. 2011

\begin{tabular}{|c|c|c|c|c|c|c|c|c|c|}
\hline \multirow{3}{*}{$\begin{array}{l}\text { S. } \\
\text { N. }\end{array}$} & \multirow{3}{*}{$\begin{array}{lll}\text { NAME } & \text { OF } & \text { THE } \\
\text { BLOCK } & & \end{array}$} & \multicolumn{6}{|c|}{ DAMAGE OF BUILDINGS } & \multirow{3}{*}{ HUT } & \multirow{3}{*}{ TOTAL } \\
\hline & & \multicolumn{3}{|c|}{ PUCCA } & \multicolumn{3}{|c|}{ RAW } & & \\
\hline & & Total & Heavily & Partial & Total & Heavily & Partial & & \\
\hline 1 & SUPAUL & 0 & 0 & 0 & 0 & 245 & 0 & 260 & 505 \\
\hline 2 & KISHANPUR & 0 & 0 & 0 & 0 & 397 & 0 & 200 & 597 \\
\hline 3 & PIPRA & 0 & 0 & 0 & 0 & 14000 & 0 & 4000 & 18000 \\
\hline 4 & TRIVENIGANJ & 0 & 0 & 0 & 0 & 250 & 0 & 160 & 410 \\
\hline 5 & CHHATAPUR & 0 & 0 & 0 & 0 & 292 & 0 & 0 & 292 \\
\hline \multicolumn{2}{|c|}{ TOTAL } & 0 & 0 & 0 & 0 & 15184 & 0 & 4620 & 19804 \\
\hline
\end{tabular}

(Source : DDMA, Supaul, 2011)

\section{MAP OF SUPAUL DIST. WITH BLOCKS}

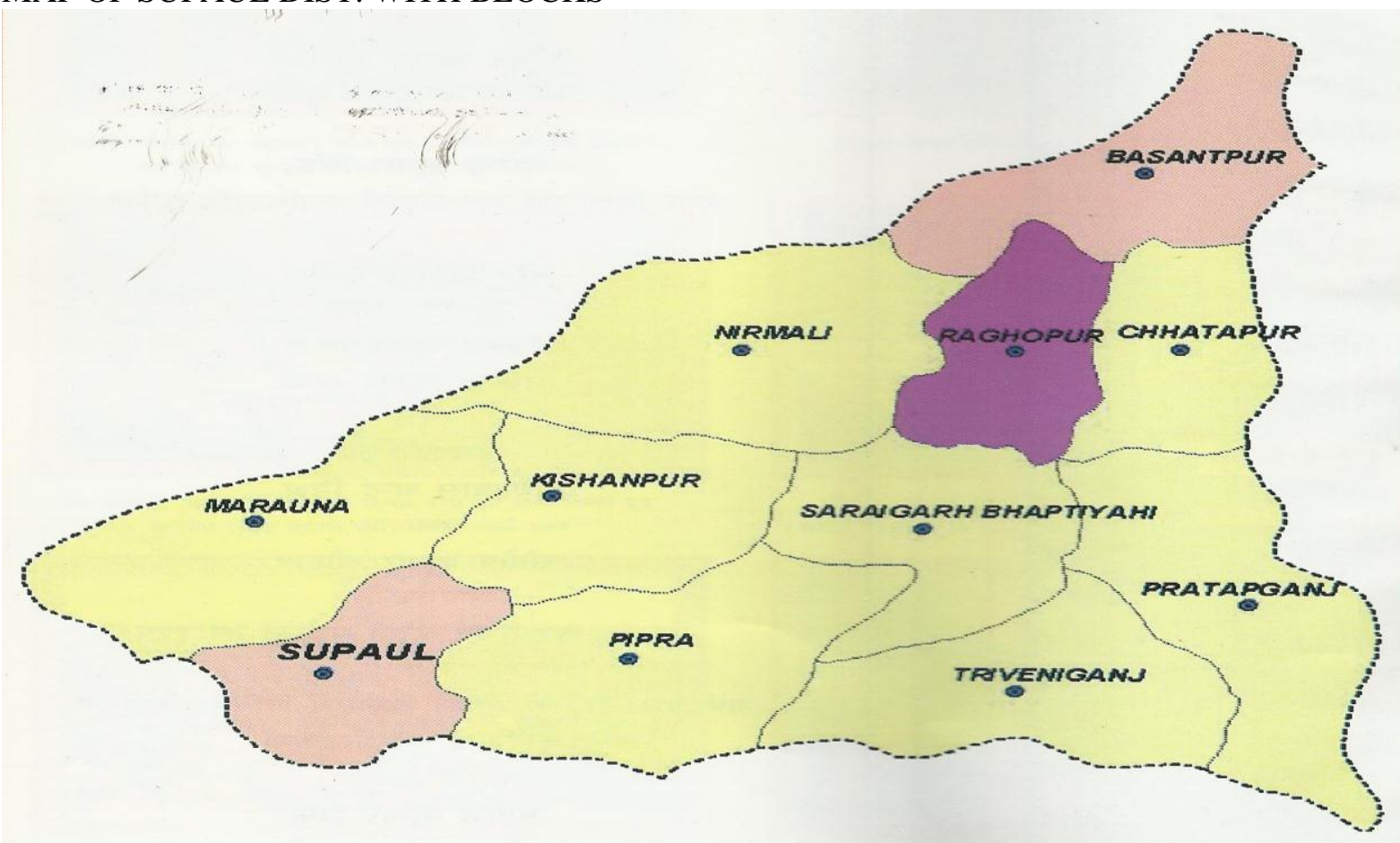

FIG. ( a- j) - A VIEW OF SUPAUL DIST. AFTER HAIL STORM 


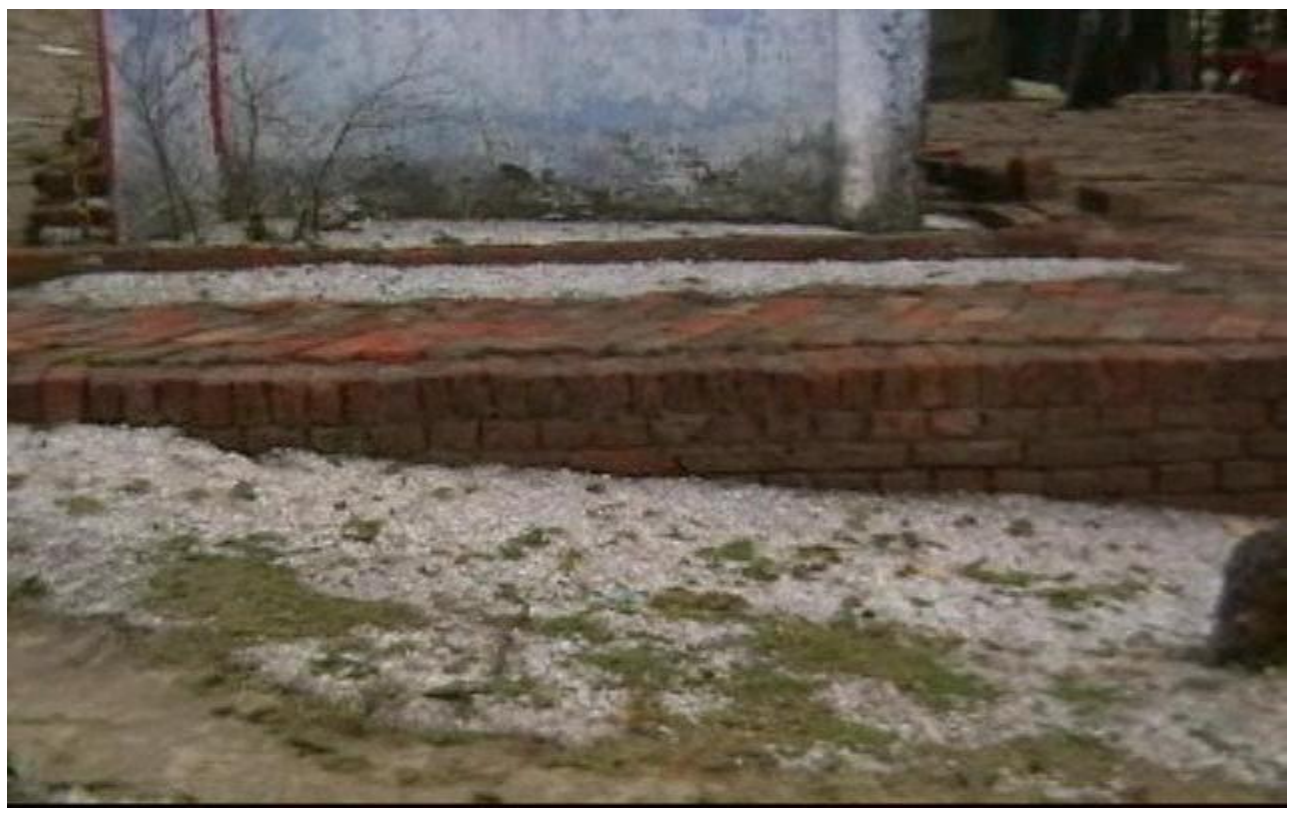

(a)

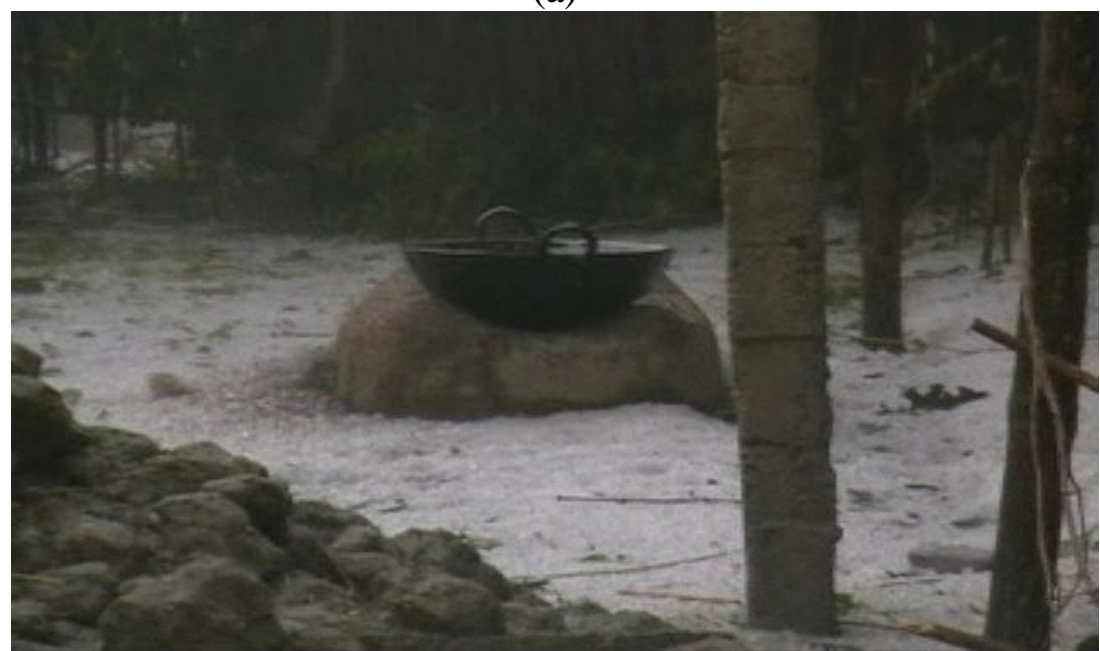

(b)

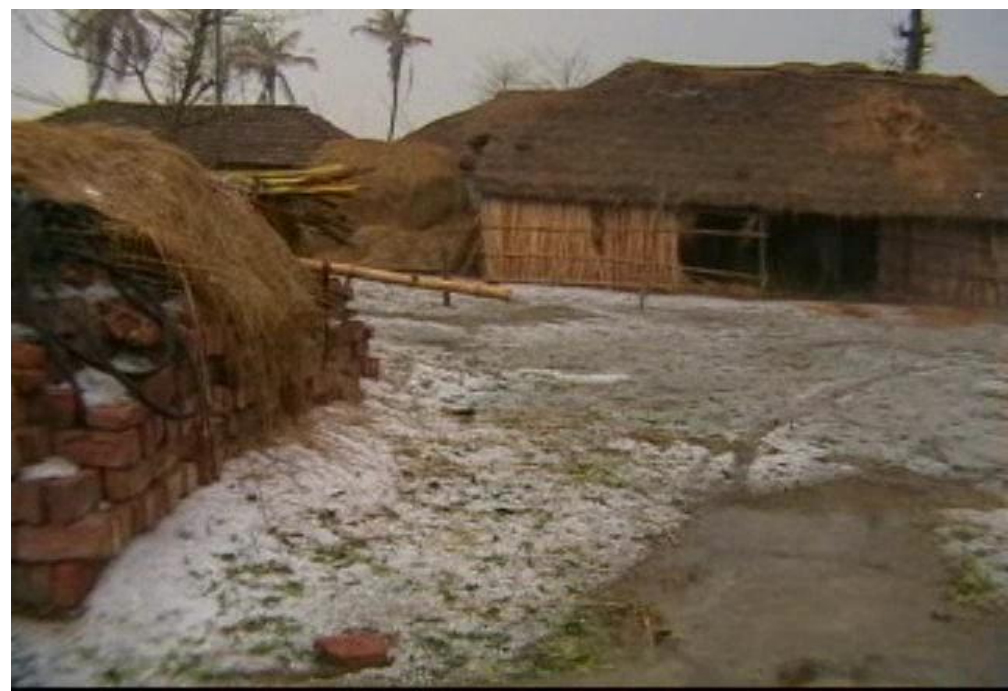

(c) 


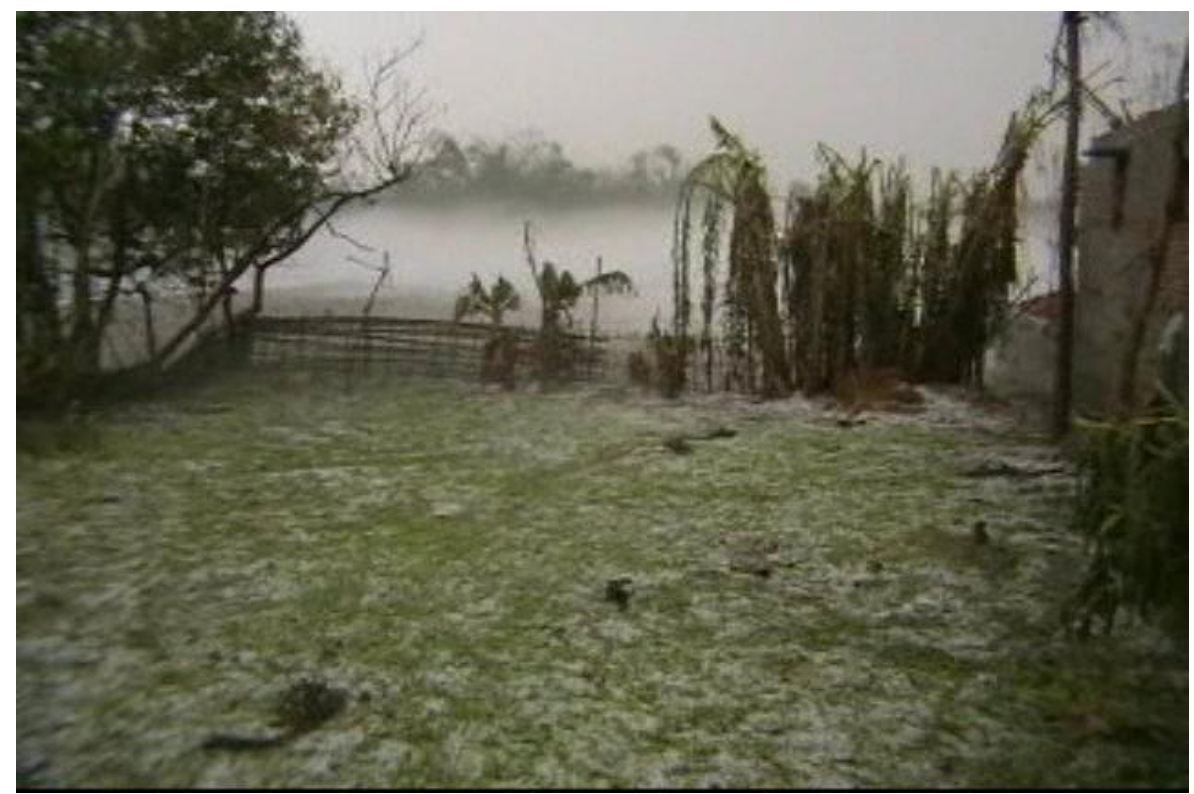

(d)

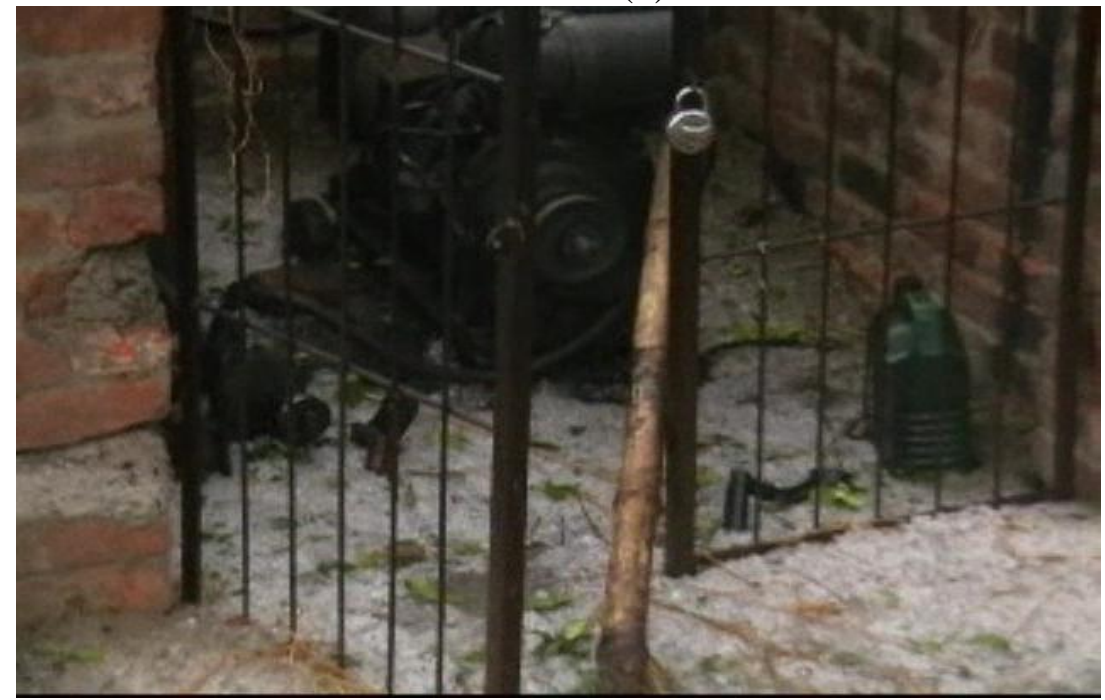

(e)

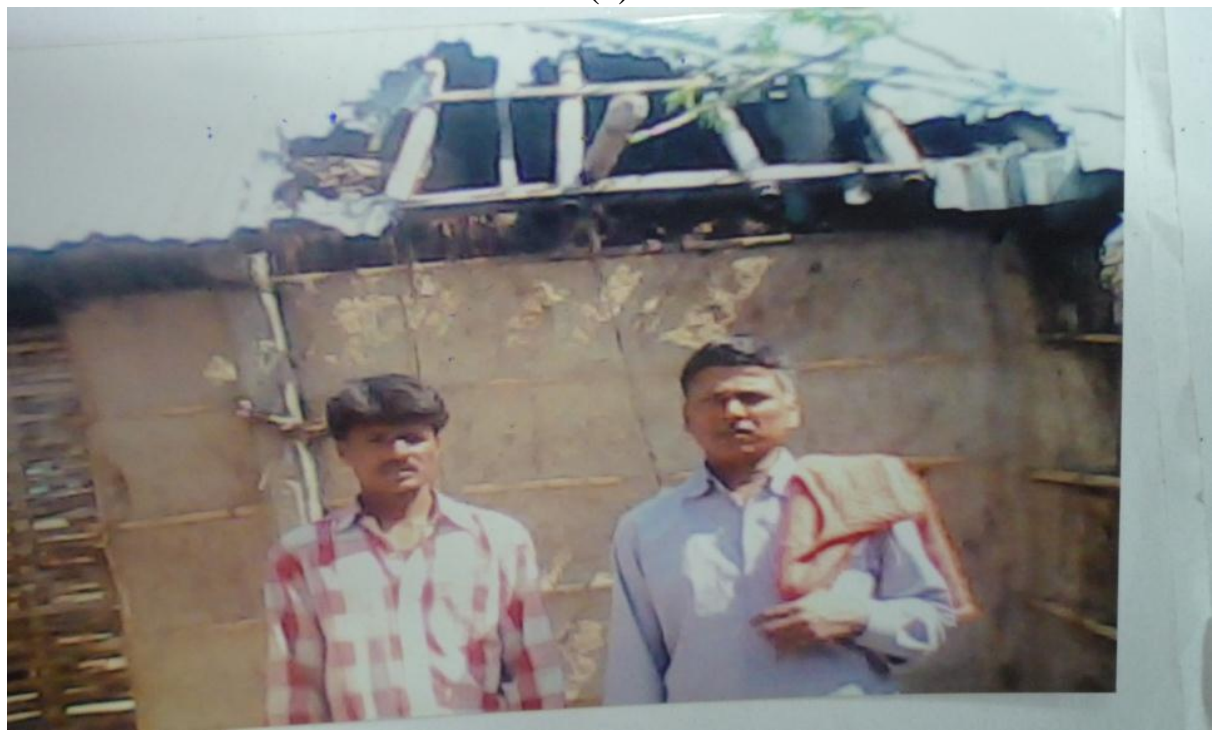

(f) 


\section{Conclusion}

Supaul had never experienced such type of unexpected hail storms. Actually the geographical and ecological features of this district are of such type that the area becomes very much sensitive to natural calamities. The State Government of Bihar has included this district in the eight selected districts for disaster management programme. The people of Supaul district is largely affected by the floods every year brought about by the devastating Koshi and Aghwara rivers. Besides this Supaul district ia also situated under the most earthquake prone zone [9]. The Himalayas is also situated in the northern side of this district in Nepal and there is a large Kusaha dam on the river Koshi towards its western side. All these features, make this district vulnerable to natural calamities. No any inhibitants of Supaul and adjoining districts can forget the devastating flood of August 2008 caused by the Koshi river district caused due to breakage of Kusaha dam. In 1988 the earthquake has already caused huge damage to this district. But the heavy hail storm with rain completely stopped the entire life activities of this area. It was totally a new surprising devastating event. This indicates that the global cooling has expanding gradually and reached up to this area also. The cold season was more intense and longer too in this year and it is still continuing. Year 2013 was also recorded cooler than 2011 and 2012 and Supaul experienced the historic minimum temperature of $2^{\circ}$ Celsius [14]. On10th January 2013 a heavy hail storm extensively damaged the Supaul District and it extended up to Saharsa, Madhepura, Madhubani, Darbhanga ,Muzaffarpur, Samastipur, Sitamarhi, Motihari, Gopalgunj, Araria , Purnea, and Katihar Districts of northern Bihar . The minimum temperature $0^{\circ} \mathrm{C}$ was recorded for the first time in Bihar in Gopalgunj [14], In 2012 too hail storms severely damaged the standing crops in Katihar Supaul and Khagaria Districts [15]. Its reason may be natural or natural and anthropogenic both. The modern tendency of human beings to achieve development at any cost has much damaged the nature. It is true that natural calamities cannot be prevented but human activities responsible for increasing natural calamities or degrading environment can be reduced and their ill effects can be minimised by proper management.

\section{Acknowledgements}

Authors are thankful to Sri Mohan Prasad, DDC and Sri Ram Bilas Choudhary, ADM (Disaster Management ) of Supaul for extending help and providing official data on damage caused due to stormy rains and hails on 16th Feb, 2011 in Supaul District.

\section{References}

[1] Sharma, J. P., P. K. Garg and H. K. Bhatia (2004). Pollution and global environmental changes. Coprehensive Biology, Laxmi Publications (P) Ltd., New Delhi, pp. 824-866.

[2] Sharma, Kuldeep (2010). And now Global Cooling. Vigyan Pragati, Hindi Monthaly, Council of Scientific and Industrial Research, New Delhi, Year 59, February : 2010, No. 2, Purnank 669, pp. 34-37.

[3] Tornqviist, T. E., S. J. Bick, J. L. Gonzalez K. van der Borg, K. and A. F. M. de Jong (2004)Tracking the sea level signature of the 8.2 ka cooling event: New constraints from the Mississippi Delta, Geophysical Research Letter, 31, L23309, doi : 1029/2004GLO21429.

[4] web.me.com (2011). Global cooling as predicted, 2011 was cool 2012 will be cooler

[5] geoff@isthereglobalwarming.com (2012). Is there global cooling? (the antitheses of global warming).

[6] Dainik Jagran (2012). Heavy snowfall caused cancellation of about 120 flights in London, Dainik newspaper, $6^{\text {th }}$ February, Bhagalpur, India.

[7] Dainik Jagran (2012). On monday Srinagar became completely covered with snow . Dainik Jagran, Hindi daily newspaper, Tuesday, $14^{\text {th }}$ February Bhagalpur, India.

[8] Hindustan (2011). Intense stormy rains damaged the crops of thousands of acres. Hindustan, Hindi Daily Newspaper, Tuesday, April 5, Bhagalpur, India.

[9] Kumar, Subhash (2011). Disaster management and Supaul. Souvenir, District Foundation Day, Supaul, pp. 19-21.

[10] DDMA (2011). Damage of crops and buildings due to stormy rains and hails on16th February 2011. Report submitted to Secretary, Agricultuse Department, Bihar Patna on 23 Feb 2011, District Disaster Managament Authority, Collectariate, Supaul, Bihar, India.

[11] Hindustan (2012). Hailstorm : the wounds of people still fresh even after one year. Hindustan, Hindi Daily Newspaper, Thursday, February 16, Bhagalpur, India.

[12] Rose, David (2012). Forget global warming- it's cycle 25 we need to worry about (and if NASA scientists are right the Thames will be freezing over again). Published by Associated Newspapers Ltd.

[13] Easterbrook, Don J. (2008). Global cooling is here. Evidence for predicting global cooling for the next three decades. Global Research, November 2, Deprtment of Geology, Western Washington University.

[14] Hindustan (2013).Temperature of the state fallen down to $0^{\circ} \mathrm{C}$, hail storm severely affected the life processes in Supaul. Hindustan, Hindi Daily Newspaper, Thursday, January 10, Bhagalpur, India.

[15] Hindustan (2012). Cyclone and hailstorm extensively damaged the standing crops, two died. Hindustan, Hindi Daily Newspaper, Sunday, April 8, Bhagalpur, India. 